DOI 10.22460/jpmi.v1i3.229-238

\title{
KEMAMPUAN MENGIDENTIFIKASI DAN MERUMUSKAN MASALAH BANGUN DATAR SERTA MINAT BELAJAR SISWA SMP
}

\author{
Indri Felani ${ }^{1}$, Tsara Nabila Ramdhani ${ }^{2}$, Heris Hendriana ${ }^{3}$ \\ 1,2,3 IKIP Siliwangi, Jl. Terusan Jenderal Sudirman, Cimahi, Jawa Barat, Indonesia \\ ${ }^{1}$ indrifelani21@gmail.com, ${ }^{2}$ tsaranabila.tn@gmail.com,3 herishen@ikipsiliwangi.ac.id
}

Diterima: 12 Maret 2018; Disetujui: 28 Mei 2018

\begin{abstract}
One of the potential that can improve student competence about mathematic is problem solving ability, because the competence is mathematic's heart. Student success for improving problem solving ability supported by students's interest in learning activity. The reaserch approach conduct this research using qualitative with descriptive method. Sample in the research consist of 35 student at the VIII-E class in SMPN 3 Cimahi. Instruments used problem solving ability test and interest in student learning scale non-tes. Based on research results obtained that problem solving ability is enough to achieve the criteria. Futhermore, the scala show that the half of student have good motivation in learning mathematics
\end{abstract}

Keywords: Mathematical Problem-Solving Abilities, Students' Interest in Learning Activity

\begin{abstract}
Abstrak
Salah satu potensi yang dapat meningkatkan kemampuan siswa terhadap pelajaran matematika adalah kemampuan pemecahan masalah karena kemampuan tersebut merupakan jantungnya matematika. Keberhasilan siswa untuk meningkatkan kemampuan pemecahan masalah juga didorong dari minat belajar siswa. Pendekatan penelitian yang digunakan adalah kualitatif dengan metode deskriptif. Sampel dalam penelitian ini terdiri dari 35 siswa kelas VIII-E di SMPN 3 Cimahi. Bentuk instrumen yang digunakan adalah tes kemampuan pemecahan masalah dan non-tes skala minat belajar. Berdasarkan hasil penelitian diperoleh bahwa pada kemampuan pemecahan masalah siswa berada pada kriteria cukup. Sedangkan pada skala terlihat lebih dari setengah jumlah siswa memiliki minat belajar yang baik terhadap pelajaran matematika.
\end{abstract}

Kata Kunci: Kemampuan Pemecahan Masalah Matematis, Minat Belajar

How to cite: Felani, I., Ramdhani, T. N., \& Hendriana, H. (2018). Kemampuan Mengidentifikasi dan Merumuskan Masalah Bangun Datar serta Minat Belajar Siswa SMP. JPMI - Jurnal Pembelajaran Matematika Inovatif, 1 (3), 229-238.

\section{PENDAHULUAN}

Pembelajaran sangat erat kaitannya dengan ilmu pengetahuan. Salah satu jenis ilmu pengetahuan yang penting dimiliki adalah matematika. Matematika merupakan salah satu mata pelajaran yang sangat berperan penting dalam keberhasilan program pendidikan, karena matematika bagian dari pendidikan akademis dan ilmu dasar bagi disiplin ilmu yang lain. Namun, masih banyak siswa SMP yang kurang menyukai pelajaran matematika. Siswa terkadang tidak terlibat secara aktif dalam penemuan konsep matematika. Putra (2011) menemukan bahwa pada salah satu SMP di Cimahi menyatakan bahwa pendekatan 
pembelajaran yang membuat siswa aktif (berbuat, mendengar, melihat, dan berpikir) dapat menumbuhkan sikap positif siswa terhadap matematika sebesar $85,93 \%$.

Penyebab lain siswa kurang menyukai pelajaran matematika adalah konsep matematika yang masih abstrak bagi siswa sehingga tahap berpikir mereka tidak dapat memahami konsep tersebut. Hasil temuan Putra (2014) pada salah satu sekolah menengah pertama dari 35 siswa dalam satu kelas, hanya 5 siswa yang sudah berada pada tahap berpikir formal (abstrak), sebanyak 30 siswa masih berada pada tahap operasi konkret, sehingga sedikit sekali siswa yang dapat memahami konsep matematika yang abstrak. Guru perlu merancang bahan ajar sesuai dengan tingkat berpikir siswa. Menurut Putra, Herman, \& Sumarmo (2017) lembar kerja yang dirancang sendiri oleh guru dapat meningkatkan kemampuan berpikir matematis siswa pada kriteria sedang. Guru lebih mengetahui penyajian materi matematika yang dapat dipahami dengan baik bagi siswa daripada hanya menggunakan buku cetak yang sudah ada karena belum tentu sesuai dengan kemampuan mereka.

Salah satu tujuan pembelajaran matematika adalah siswa memiliki kemampuan pemecahan masalah. Belajar matematika mendorong siswa untuk berusaha sendiri mencari pemecahan masalah sehingga pengetahuan yang diperoleh benar-benar bermakna. Konsekuensinya adalah siswa akan mampu menyelesaikan masalah-masalah serupa ataupun berbeda dengan baik karena siswa mendapat pengalaman konkret dari masalah yang terdahulu Trianto (Hertiavi, Langlang, \& Khanafiyah, 2010).

Kemampuan pemecahan masalah matematis siswa sangat penting untuk dikembangkan. Pentingnya pemecahan masalah dikemukakan Branca (Effendi, 2012), ia mengemukakan bahwa kemampuan pemecahan masalah adalah jantungnya matematika. Hal ini sejalan menurut NCTM (Effendi, 2012) yang menyatakan bahwa pemecahan masalah merupakan bagian integral dalam pembelajaran matematika, sehingga hal tersebut tidak boleh dilepaskan dari pembelajaran matematika. Pemecahan masalah dianggap memiliki keterkaitan kuat dengan matematika atau intinya bermatematika (Minarni, 2012).

Kemampuan pemecahan masalah matematika siswa dapat dilihat dari hasil survei TIMSS yang dikoordinasikan oleh IEA (The International Assosciation for the Evaluation of Educational Achievement) dengan salah satu indikator kognitif yang dinilai adalah kemampuan siswa dalam memecahkan masalah non rutin dari hasil survei tersebut diperoleh bahwa posisi Indonesia dalam setiap keikutsertaan selalu memperoleh nilai dibawah rata-rata yang telah ditetapkan. Hendriana, Rohaeti, \& Sumarmo (2017) mengungkapkan indikator pemecahan masalah matematis sebagai berikut: 1) Mengidentifikasi unsur-unsur yang diketahui, ditanyakan, dan kecukupan unsur yang diperlukan. 2) Merumuskan masalah matematik atau menyusun model matematik. 3) Menerapkan strategi untuk menyelesaikan masalah sehari-hari. 4) Menjelaskan atau menginterpretasikan hasil sesuai permasalahan awal. 5) Menggunakan matematika secara bermakna.

Keterampilan memahami masalah, membuat model matematika, menyelesaikan masalah dan menafsirkan solusinya merupakan upaya dalam meningkatkan kemampuan pemecahan masalah. Hal ini didukung oleh Polya (Suherman et al., 2003), yang menyatakan solusi soal pemecahan masalah memuat empat langkah penyelesaian, yaitu memahami masalah, merencanakan penyelesaian, menyelesaikan masalah sesuai rencana dan melakukan pengecekan kembali terhadap semua langkah yang telah dikerjakan. 
Keberhasilan belajar seseorang dapat dipengaruhi oleh beberapa faktor, baik dari dalam diri maupun dari luar yang bersangkutan. Satu dari dalam diri seseorang yang mungkin dapat mempengaruhi hasil belajarnya adalah minat belajar. Minat siswa merupakan faktor utama yang menentukan derajat keaktifan siswa, bila bahan pelajaran yang dipelajari tidak sesuai dengan minat siswa, siswa tidak akan belajar dengan sebaik-baiknya, sebab tidak ada daya tarik baginya (Nugroho, Afandi, \& Abdullah, 2014). Minat belajar yang tinggi akan memudahkan siswa mencapai tujuan belajar. Sedangkan kurangnya minat belajar dapat mengakibatkan kurangnya rasa ketertarikan seseorang terhadap suatu bidang tertentu terutama matematika, bahkan dapat melahirkan sikap penolakan terhadap guru. Beberapa penelitian di Amerika Serikat menunjukan bahwa kegagalan studi para pelajar antara lain karena kurangnya minat belajar menurut Gie (Hendriana et al., 2017).

Minat merupakan suatu kegiatan yang dilakukan siswa secara konsekuen dalam pembelajaran. Hal ini sejalan dengan pendapat Slameto (2010) minat adalah kecenderungan yang kensekuen untuk memperhatikan dan mengingat suatu kegiatan. Selanjutnya minat memiliki penjelasan suatu rasa ketertarikan atau rasa senang saat melakukan suatu kegiatan. Seseorang yang memiliki minat belajar akan bersungguh-sungguh dalam melakukan pembelajaran dan tidak perlu adanya dorongan dari orang lain. Minat belajar memiliki lima indikator yaitu: perasaan senang, ketertarikan siswa, keterlibatan siswa, rajin dalam belajar dan rajin mengerjakan tugas matematika, serta tekun dan disiplin dalam belajar dan memiliki jadwal belajar (Hendriana et al., 2017).

Berdasarkan uraian diatas, perlu dilakukan analisis lebih lanjut terhadap kemampuan mengidentifikasi unsur-unsur yang diperlukan dan kemampuan merumuskan masalah matematis serta minat belajar siswa terhadap pelajaran matematika pada siswa SMP. Rumusan masalah dalam penelitian ini adalah bagaimana kemampuan mengidentifikasi unsur-unsur yang diperlukan dan kemampuan merumuskan masalah matematis serta minat belajar siswa SMP terhadap pelajaran matematika.

\section{METODE}

Metode penelitian yang digunakan yaitu metode deskriptif dengan pendekatan kualitatif. Penelitian ini dilakukan di SMPN 3 Cimahi kelas VIII-E pada tahun pelajaran 2017/2018 yang terdiri dari 35 siswa. Data diperoleh dari dua jenis instrumen yaitu soal tes kemampuan pemecahan masalah dan skala minat belajar siswa. Soal tes kemampuan pemecahan masalah yang digunakan terdiri dari satu butir soal yang memiliki dua indikator pemecahan masalah yaitu mengidentifikasi kecukupan unsur-unsur yang diperlukan dan merumuskan masalah matematik pada materi segitiga dan segiempat. Skala minat belajar bertujuan untuk mengetahui ketertarikan siswa terhadap pembelajaran matematika yang terdiri dari 30 pernyataan.

Kedua data dibandingkan untuk menguji keabsahannya dengan menggunakan teknik analisis data yang terdiri dari memeriksa jawaban siswa berdasarkan tes kemampuan pemecahan masalah, menganalisis jenis-jenis kesalahan yang dilakukan siswa dalam menyelesaikan tes dan disesuaikan dengan hasil analisis skala minat belajar. Data yang sudah diperoleh selanjutnya dianalisis secara deskriptif.

Untuk memperoleh data persentase kemampuan pemecahan masalah siswa menggunakan rumus sebagai berikut: 
232 Felani, Ramdhani, \& Hendriana, Kemampuan Mengidentifikasi dan Merumuskan ...

$$
\text { Nilai }=\frac{\text { Skor Siswa }}{\text { Skor Ideal }} \times 100 \%
$$

Skor ideal pada soal adalah 10. Kriteria kemampuan pemecahan masalah matematik siswa menurut Arikunto (2007) disajikan pada Tabel 1 berikut ini.

Tabel 1. Kriteria Pemecahan Masalah

\begin{tabular}{cc}
\hline Nilai & Kriteria \\
\hline $68 \%-100 \%$ & Tinggi \\
\hline $33 \%-67 \%$ & Cukup \\
\hline$<33 \%$ & Rendah \\
\hline
\end{tabular}

\section{HASIL DAN PEMBAHASAN}

Data yang diperoleh dari hasil tes kemampuan pemecahan masalah dan hasil skala minat belajar siwa kemudian dilakukan analisis untuk memperoleh gambaran kemampuan pemecahan masalah dan minat belajar.

\section{Kemampuan Pemecahan Masalah Matematik Siswa}

Pada Tabel 2 berikut ini menampilkan skor yang diperoleh siswa berdasrkan jawaban yang mereka berikan terhadap soal yang memuat indikator kemampuan pemecahan masalah.

Tabel 2. Rekapitulasi Nilai Siswa

\begin{tabular}{|c|c|c|c|c|c|}
\hline Skor & Nilai & Jumlah & Siswa & Kriteria & Analisis Kesalahan \\
\hline 10 & $100 \%$ & - & - & - & 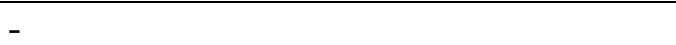 \\
\hline 9 & $90 \%$ & - & - & - & - \\
\hline 8 & $80 \%$ & - & - & - & - \\
\hline 7 & $70 \%$ & - & - & - & - \\
\hline 6 & $60 \%$ & 6 & $17,14 \%$ & Cukup & $\begin{array}{l}\text { Siswa salah dalam menentukan konsep } \\
\text { dari masalah yang disajikan sehingga }\end{array}$ \\
\hline 5 & $50 \%$ & 18 & $51,42 \%$ & Cukup & $\begin{array}{l}\text { nilai akhir yang didapatkan kurang } \\
\text { tepat. }\end{array}$ \\
\hline 4 & $40 \%$ & 5 & $15,15 \%$ & Cukup & $\begin{array}{l}\text { Siswa tidak memahami konsep yang } \\
\text { disajikan dalam masalah. } \\
\text { Siswa tidak memahami materi segitiga, } \\
\text { siswa hanya memahami materi } \\
\text { segiempat. } \\
\text { Hasil akhir yang didapat tidak tepat. }\end{array}$ \\
\hline 3 & $30 \%$ & 6 & $17,14 \%$ & Rendah & $\begin{array}{l}\text { Siswa tidak memahami konsep segitiga } \\
\text { dan segiempat sehingga salah dalam } \\
\text { menuliskan langkah-langkah } \\
\text { penyelesaian. } \\
\text { Tidak ada hasil akhir yang diperoleh. }\end{array}$ \\
\hline 2 & $20 \%$ & - & - & - & - \\
\hline 1 & $10 \%$ & - & - & - & - \\
\hline
\end{tabular}


Berdasarkan Tabel 2 dapat dilihat dari 35 siswa, terdapat 29 siswa $(83,71 \%)$ yang mendapatkan kriteria cukup pada kemampuan pemecahan masalah, sedangkan yang mendapatkan kriteria rendah sebanyak 6 siswa $(17,14 \%)$. Berdasarkan persentase di atas, dapat dinyatakan bahwa sebagian besar siswa masuk dalam kriteria cukup dalam kemampuan pemecahan masalah disebabkan siswa kurang dibiasakan dalam menyelesaikan soal-soal kemampuan pemecahan masalah. Apabila siswa lebih dilatih dalam menyelesaiakan soal-soal kemampuan pemecahan masalah maka kemampuan mereka akan pada kriteria tinggi.

\section{Analisis Kesalahan Jawaban Siswa}

Pada tahap ini akan dibahas mengenai jawaban siswa yang mewakili setiap skor kemampuan pemecahan masalah matematis. Berikut ini disajikan soal yang memuat indikator kemampuan pemecahan masalah beserta jawaban siswa untuk mengetahui proses pemecahan masalah.

Selembar kertas karton yang berbentuk persegi panjang dilipat seperti yang terlihat pada gambar di bawah ini. Cukupkah informasi tersebut untuk menemukan luas daerah yang berwarna hitam? Jika cukup selesaikanlah masalah tersebut. Jika tidak cukup, lengkapi kemudian susunlah jawaban-jawabanmu yang berbeda dari keterangan tersebut, kemudian selesaikan!

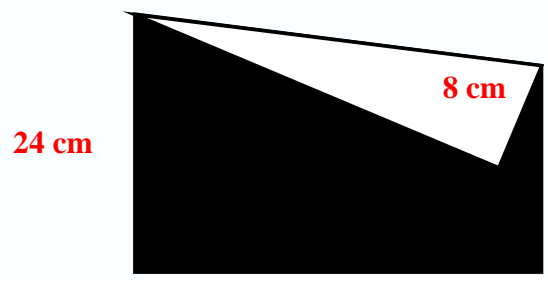

Berdasarkan soal yang diberikan diperoleh berbagai macam jawaban yang siswa berikan. Berikut ini disajikan perwakilan jawaban siswa dari tiap-tiap skor kemampuan pemecahan masalah yang diperoleh.

\section{Analisis Jawaban Siswa dengan Skor 6}

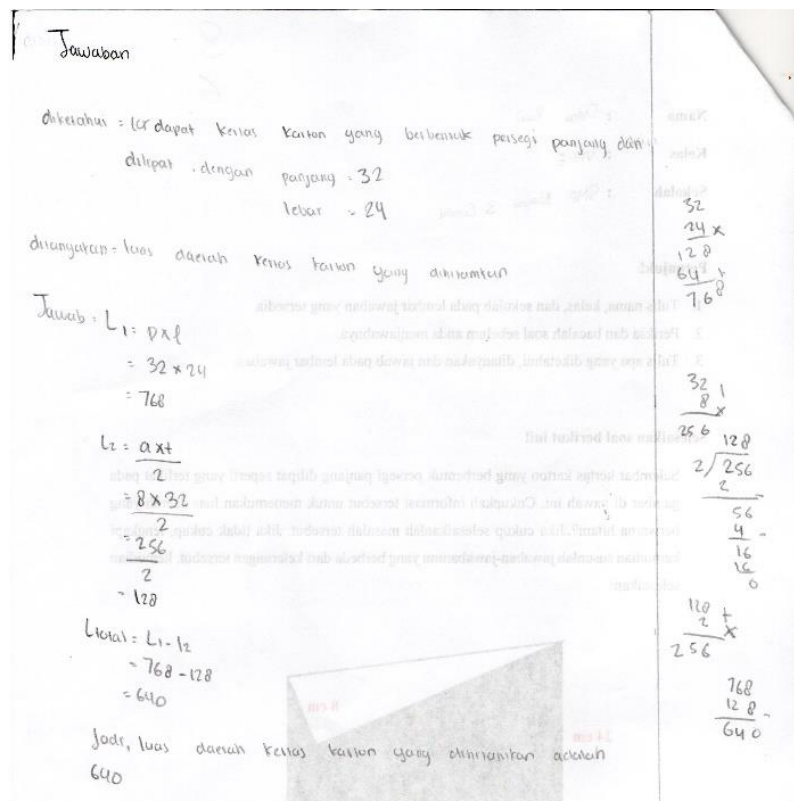

Gambar 1. Jawaban Siswa yang Memiliki Skor 6 (Kriteria Cukup) 
Analisis jawaban siswa: Pada gambar 1 dapat dilihat bahwa siswa melakukan pengamatan terhadap gambar kertas karton yang dilipat dengan lebar $24 \mathrm{~cm}$ dan panjang lipatan $8 \mathrm{~cm}$. Untuk menentukan luas karton berwarna hitam atau luas kertas karton yang tidak terlipat, siswa melakukan perhitungan terhadap luas karton utuh sebelum dilipat (luas persegi panjang) dengan melengkapi unsur yang diperlukan yaitu panjang karton $32 \mathrm{~cm}$ sehingga didapatkan luas karton utuh yaitu $768 \mathrm{~cm}^{2}$. Selanjutnya siswa melakukan perhitungan terhadap luas lipatan karton (luas segitiga) sehingga didapatkan luasnya yaitu $128 \mathrm{~cm}^{2}$.

Setelah siswa menemukan luas persegi panjang dan luas segitiga, selanjutnya siswa melakukan langkah terakhir untuk menemukan kertas karton yang tidak terlipat dengan cara mengurangkan luas persegi panjang dengan luas segitiga sehingga diperoleh hasil $640 \mathrm{~cm}^{2}$. Pada langkah terakhir siswa melakukan kesalahan yang seharusnya luas persegi panjang dikurangkan dengan dua kali luas segitiga. Siswa memahami cara menemukan luas segitiga dan segiempat hanya saja siswa kurang memahami konsep dari soal yang diberikan. Sehinga hasil akhir yang diperoleh kurang tepat.

Berdasarkan skala minat belajar diperoleh informasi bahwa siswa menyukai pelajaran matematika. Siswa aktif selama pembelajaran dikelas dan menyukai cara guru dalam menyampaikan materi hanya saja siswa kurang dapat memahami soal yang diberikan sehingga hasil akhir yang ditemukan tidak tepat.

\section{Analisis Jawaban Siswa dengan Skor 5}

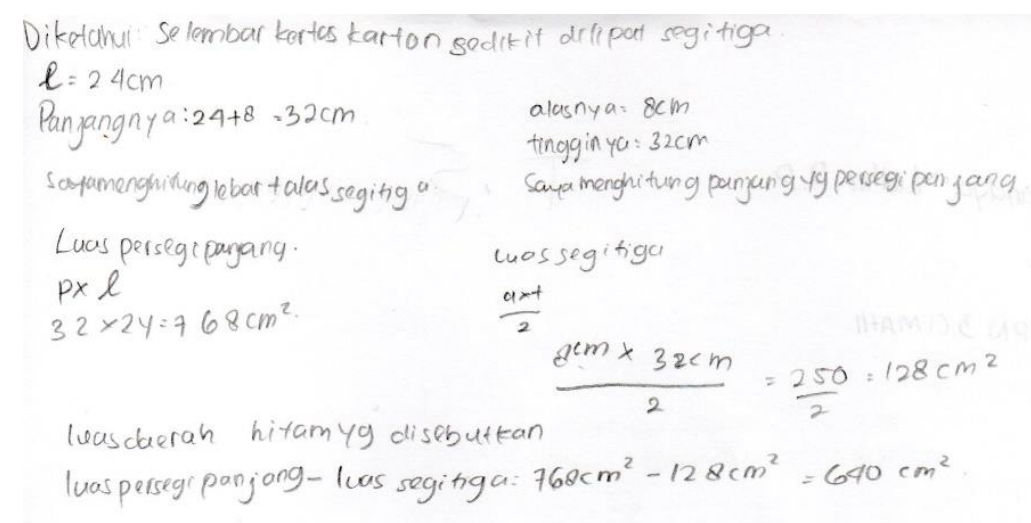

\section{Gambar 2. Jawaban Siswa yang Memiliki Skor 5 (Kriteria Cukup)}

Analisis jawaban siswa: Pada gambar 2 dapat dilihat bahwa siswa melakukan pengamatan terhadap gambar kertas karton yang dilipat dengan lebar $24 \mathrm{~cm}$ dan panjang lipatan $8 \mathrm{~cm}$. Untuk menentukan luas karton berwarna hitam atau luas kertas karton yang tidak terlipat, siswa melakukan perhitungan terhadap luas karton utuh sebelum dilipat (luas persegi panjang) dengan melengkapi unsur yang diperlukan yaitu panjang karton $32 \mathrm{~cm}$ sehingga didapatkan luas karton utuh yaitu $768 \mathrm{~cm}^{2}$. Selanjutnya siswa melakukan perhitungan terhadap luas lipatan karton (luas segitiga) sehingga didapatkan luasnya yaitu $128 \mathrm{~cm}^{2}$.

Setelah siswa menemukan luas persegi panjang dan luas segitiga, selanjutnya siswa melakukan langkah terakhir untuk menemukan kertas karton yang tidak terlipat dengan cara 
mengurangkan luas persegi panjang dengan luas segitiga sehingga diperoleh hasil $640 \mathrm{~cm}^{2}$. Pada langkah terakhir siswa melakukan kesalahan yang seharusnya luas persegi panjang dikurangkan dengan dua kali luas segitiga sehingga diperoleh hasil $512 \mathrm{~cm}^{2}$. Siswa memahami cara menemukan luas segitiga dan segiempat hanya saja siswa kurang memahami konsep dari soal yang diberikan. Sehinga hasil akhir yang diperoleh kurang tepat.

Berdasarkan skala minat belajar diperoleh informasi bahwa siswa menyukai pelajaran matematika. Siswa aktif selama pembelajaran dikelas, menyukai cara guru dalam menyampaikan materi dan siswa belajar matematika mandiri dirumah hanya saja siswa kurang dapat memahami soal yang diberikan sehingga hasil akhir yang ditemukan tidak tepat.

\section{Analisis Jawaban Siswa dengan Skor 4}

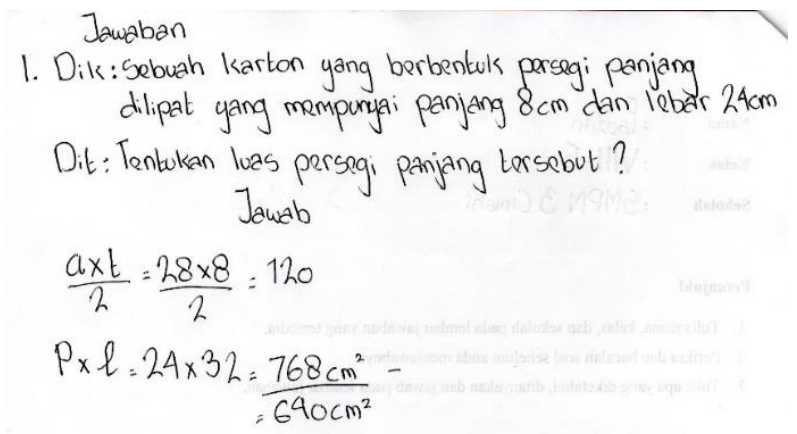

Gambar 3. Jawaban Siswa yang Memiliki Skor 4 (Kriteria Cukup)

Analisis jawaban siswa: Pada gambar 4 dapat dilihat bahwa siswa melakukan pengamatan terhadap gambar kertas karton dengan lebar $24 \mathrm{~cm}$ dan panjang lipatan $8 \mathrm{~cm}$. Untuk menentukan luas karton yang berwarna hitam, siswa menghitung luas karton utuh (luas persegi panjang) yaitu $768 \mathrm{~cm}^{2}$. Selanjutnya siswa menghitung luas lipatan (luas segitiga) namun hasilnya tidak tepat seharusnya $\frac{1}{2}(8 \mathrm{~cm} \mathrm{x} 32 \mathrm{~cm})=128 \mathrm{~cm}^{2}$. Langkah selanjutnya yang harus dilakukan siswa adalah mengurangkan luas segiempat dengan dua kali luas segitiga sehingga diperoleh hasil $512 \mathrm{~cm}^{2}$. Siswa memahami materi segiempat namun siswa tidak memahami materi segitiga sehingga siswa tidak dapat memahami soal yang diberikan serta tidak dapat menentukan hasil akhir.

Berdasarkan skala minat belajar diperoleh informasi bahwa siswa menyukai pelajaran matematika namun sesekali ia merasa bosan karena ia tidak menggunakan alat peraga yang membuatnya mudah dalam belajar matematika sehingga mengakibatkan siswa kurang memahami materi segitiga dan tidak dapat menyelesaikan soal dengan baik.

\section{Analisis Jawaban Siswa dengan Skor 3}

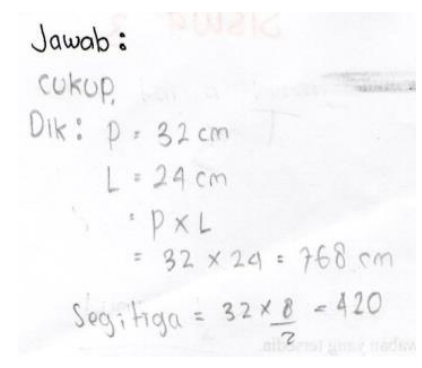

Gambar 4. Jawaban Siswa yang Memiliki Skor 3 (Kriteria Rendah) 
Analisis jawaban siswa: Pada gambar 4 dapat dilihat bahwa siswa melakukan pengamatan terhadap gambar kertas karton yang dilipat dengan lebar $24 \mathrm{~cm}$ dan panjang lipatan $8 \mathrm{~cm}$. Untuk menentukan luas karton berwarna hitam atau luas kertas karton yang tidak terlipat, siswa melakukan perhitungan terhadap luas karton utuh sebelum dilipat (luas persegi panjang) dengan melengkapi unsur yang diperlukan yaitu panjang karton $32 \mathrm{~cm}$ sehingga didapatkan luas karton utuh yaitu $768 \mathrm{~cm}^{2}$. Selanjutnya siswa melakukan perhitungan untuk menemukan luas karton yang dilipat (luas segitiga), namun siswa membuat kesalahan dalam operasi hitung sehingga jawaban yang dihasilkan $420 \mathrm{~cm}^{2}$ sedangkan jawaban yang benar adalah $128 \mathrm{~cm}^{2}$. Siswa memahami konsep segiempat dan segitiga namun siswa kurang teliti saat melakukan operasi hitung serta siswa tidak memahami konsep dari soal yang diberikan sehingga tidak ada hasil akhir yang diperoleh.

Berdasarkan skala minat belajar diperoleh informasi bahwa ketertarikan siswa terhadap pelajaran matematika tergolong tinggi namun ada beberapa faktor yang menyebabkan siswa tidak dapat menyelesaikan soal yaitu siswa hanya melihat tayangan televisi yang ia sukai dan tidak berhubungan dengan matematika. Siswa selalu mengulangi kesalahan-kesalahan yang terjadi dimasa lalu sehingga siswa sulit untuk menemukan konsep pada soal.

\section{Minat Belajar Siswa}

Minat belajar siswa terdiri dari lima indikator, yaitu: 1) perasaan senang, 2) ketertarikan siswa, 3) keterlibatan siswa, 4) rajin dalam belajar dan rajin dalam mengerjakan tugas matematika, serta 5) tekun dan disiplin dalam belajar dan memiliki jadwal belajar. Pada tabel 3 berikut ini disajikan persentase minat belajar dari 35 siswa dalam pelajaran matematika.

Tabel 3. Persentase Minat Belajar Siswa

\begin{tabular}{llrc}
\hline No. & Indikator & Setuju & Tidak Setuju \\
\hline 1. & Perasaan senang & $77 \%$ & $23 \%$ \\
2. & Ketertarikan siswa & $72 \%$ & $28 \%$ \\
3. & Keterlibatan siswa & $77 \%$ & $23 \%$ \\
4. $\quad$ Rajin dalam belajar dan rajin dalam & $67 \%$ & $33 \%$ \\
$\quad \quad$ mengerjakan tugas matematika & & \\
5. $\quad$ Tekun dan disiplin dalam belajar dan memiliki & $74 \%$ & $26 \%$ \\
$\quad \quad$ jadwal belajar & $73,4 \%$ & $26,6 \%$ \\
Rata-rata & & \\
\hline
\end{tabular}

Berdasarkan Tabel 3 terlihat bahwa sebagian besar (77\%) siswa merasa senang terhadap pelajaran matematika sedangkan sebagian kecil (23\%) siswa tidak merasa senang pada pelajaran matematika. Lebih dari setengah (72\%) siswa merasa tertarik pada pelajaran matematika sedangkan (28\%) siswa merasa tidak tertarik terhadap pelajaran matematika. Sebagian besar (77\%) siswa terlibat atau aktif pada saat pembelajaran matematika berlangsung. Siswa rajin dalam belajar dan rajin dalam mengerjakan tugas matematika (67\%) dan sebagian besar (74\%) siswa tekun dan disiplin dalam belajar dan memiliki jadwal belajar. Dilihat secara keseluruhan dapat disimpulkan bahwa sebagian besar $(73,4 \%)$ siswa memiliki minat belajar yang baik terhadap pelajaran matematika. Sedangkan $26,6 \%$ siswa memiliki minat belajar yang kurang terhadap pelajaran matematika. 


\section{KESIMPULAN}

Berdasarkan hasil penelitian yang dilakukan di SMP Negeri 3 Cimahi pada sisswa kelas VIII E diperoleh informasi bahwa kemampuan siswa dalam mengindentifikasi kecukupan data dan merumuskan masalah matematik belum dapat dikatakan baik karena sebagian siswa memperoleh skor pada kategori cukup. Tidak ada siswa yang mendapat skor sempurna, skor tertinggi yang diperoleh siswa adalah 6 dari skor sempurna 10. Kesalahan siswa pada umumnya terletak pada pemahaman konsep soal.

Kesalahan lain yang dilakukan siswa yaitu terdapat pada saat siswa melakukan operasi bilangan bulat, siswa cenderung ceroboh dalam menghitung serta kurang memahami konsep perkalian pecahan sehingga hasil yang didapatkan tidak tepat. Berdsarkan kondisi tersebut dapat dikatakan siswa belum terbiasa menyelesaikan soal kemampuan pemecahan masalah dengan aspek mengidentifikasi kecukupan unsur dan merumuskan masalah matematik, sehingga mereka sulit dalam memahami maksud, tujuan dan penyelesaian soal yang diberikan sehingga perlu ditingkatkan lagi dalam mengerjakan soal-soal pemecahan masalah siswa dapat melakukan pemecahan masalah dengan baik.

Hasil yang diperoleh dari analisis skala minat belajar siswa dapat disimpulkan bahwa sebagian besar siswa memiliki minat belajar yang baik terhadap pelajaran matematika dan sebagian kecil siswa tidak memiliki minat belajar yang baik terhadap pelajaran matematika. Meskipun sebagian besar kemampuan pemecahan masalah siswa masih tergolong cukup namun sebagian besar siswa sudah memiliki minat belajar yang baik sehingga dapat dikatakan bahwa meskipun siswa mengalami kesulitan pada saat menyelesaikan soal kemampuan pemecahan masalah matematik, tetapi tidak membuat minat belajar siswa terhadap pelajaran matematika rendah.

\section{DAFTAR PUSTAKA}

Arikunto, S. (2007). Dasar-Dasar Evaluasi Pendidikan. Jakarta: Bumi Aksara.

Effendi, L. A. (2012). Pembelajaran Matematika dengan Metode Penemuan Terbimbing untuk Meningkatkan Kemampuan Representasi dan Pemecahan Masalah Matematis Siswa SMP. Jurnal Penelitian Pendidikan, 13(2).

Hendriana, H., Rohaeti, E. E., \& Sumarmo, U. (2017). Hard Skills dan Soft Skills Matematik Siswa. Bandung: Refika Aditama.

Hertiavi, M. A., Langlang, H., \& Khanafiyah, S. (2010). Penerapan Model Pembelajaran Kooperatif Tipe Jigsaw untuk Peningkatan Kemampuan Pemecahan Masalah Siswa SMP. Jurnal Pendidikan Fisika Indonesia, (6), 53-57.

Minarni, A. (2012). Pengaruh Pembelajaran Berbasis Masalah Terhadap Kemampuan Pemecahan Masalah Matematis. In Prosiding Seminar Nasional Matematika dan Pendidikan Matematika FMIPA UNY.

Nugroho, W., Afandi, A., \& Abdullah, I, H. (2014). Penerapan Pembelajaran Pemecahan Masalah Pada Spek Minat Belajar Matematika Siswa SMP. Jurnal Matematika Dan Pendidikan Matematika, 3(2).

Putra, H. D. (2011). Pembelajaran Geometri dengan Pendekatan SAVI Berbantuan Wingeom untuk Meningkatkan Kemampuan Analogi Matematis Siswa SMP. Seminar Nasional Pendidikan Matematika, 1, 292-302. 
238 Felani, Ramdhani, \& Hendriana, Kemampuan Mengidentifikasi dan Merumuskan ...

Putra, H. D. (2014). Tahap Perkembangan Kognitif Matematika Siswa MTs Asy Syifa Kelas IX Berdasarkan Teori Piaget. In Prosiding Seminar Nasional Pendidikan Matematika (pp. 224-230). cimahi: STKIP Siliwangi.

Putra, H. D., Herman, T., \& Sumarmo, U. (2017). Development of Student Worksheets to Improve the Ability of Mathematical Problem Posing. International Journal on Emerging Mathematics Education, 1(1), 1-10.

Slameto. (2010). Belajar dan Faktor-Faktor yang Mempengaruhinya. Jakarta: Rineka Cipta.

Suherman, E., Turmudi, Suryadi, D., Herman, T., Suhendra, Prabawanto, S., Nurjanah \& Rohayati, A. (2003). Strategi Pembelajaran Matematika Kontemporer. Bandung: Universitas Pendidikan Indonesia. 